\title{
Førstehjelp ved selvmordsfare: Hva kan folk uten helsefaglig bakgrunn gjøre?
}

\author{
Ved Kirsti Silvola
}

\begin{abstract}
Førstehjelp ved selumordsfare er som hjerte-/lungeredning eller intervensjon ved trafikkulykker: en måte å redde liv på eller å forhindre skade i akutte krisesituasjoner. Førstehjelp ved selumordsfare utøves av de som først kommer i kontakt med personer som står i fare for å ta sitt eget liv. Dette er noe helt annet enn languarig oppfølging og behandling.
\end{abstract}

I denne sammenheng kan det være nyttig å minne om hvordan kunnskap om førstehjelp har reddet mange trafikkskadde fra å dø en unødvendig død med passive og hjelpeløse tilskuere på åstedet. Slik er det også med sel vmordskriser. Dersom brede grupper i folket etter hvert tilegner seg elementære kunnskaper om hvordan de kan gi førstehjelp i en slik krise og sørge for mer omfattende hjelp fra fagfolk, kan trolig flere selvmordsnære mennesker reddes. Både fagfolk med og uten helsefaglig bakgrunn har nytte av slike førstehjel psferdigheter.

De som først kommer i kontakt med mennesker som har selvmordstanker, er ofte andre enn folk med helsefaglig bakgrunn. M en det er ikke alltid så lett å gripe inn. Det kan være at man ikke kan tolke faresignaler eller at man er så redd og hjel peløs at man heller trekker seg unna.

Det finnes misoppfatninger om selvmord som kan gjøre det vanskelig å gripe inn. "M an skal ikke snakke om selvmord, eller spørre direkte om selvmordstanker, fordi det kan gi vedkommende en idé om å ta sitt eget liv" er en veldig utbredt misoppfatning som kan bli et hinder for adekvat hjelp.

$\mathrm{H}$ va må til for at flere personer kunne føle seg trygge i det å gripe inn? Det er viktig å tilegne seg holdninger som støtter dem i det å bry seg om hverandre, ha elementær kunnskap om faresignaler og risikovurdering, samt kunnskap og ferdigheter om intervensjon i akutte sel vmordskriser. U ndervisningsprosjektet Vivat som er en del av "Tiltak mot selvmord", tilbyr kurset "Førstehjelp ved selvmordsfare". G jennom det kan man få både kunnskap og ferdigheter i forhold til akutt intervenering. Vivat utdanner lokale kursledere som kan undervise på kurset. Det går over to dager, og vanligvis deltar ca. 24 deltakere og to kursledere. Dette kurset er ment for alle som i sitt virke kan møte selvmordsnære mennesker. H ittil har ca. 2800 mennesker deltatt på kurset, og av disse kommer ca. en tredjedel fra miljøer utenom helsevesenet. O gså kursledere er en tverrfaglig gruppe.

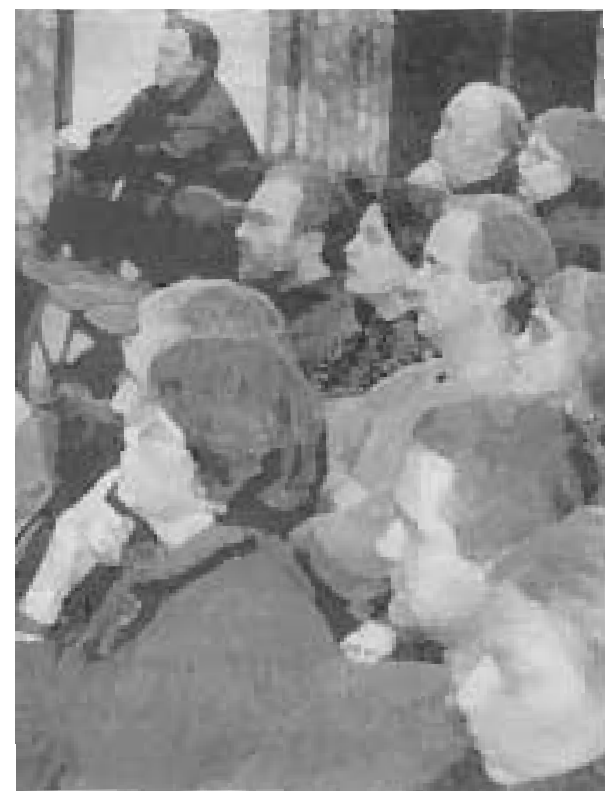

$20 \%$ av de 96 kursledere her i landet representerer politi, skoleverket og Kirken. Et viktig aspekt ved kurset er å blande flere typer fagpersoner og ufaglærte, slik at de kan dele sine erfaringer og lære av hverandre. De aller fleste kursdeltakerne opplever økt kompetanse som nyttig. Jeg har "e-postintervjuet" noen deltakere 1/2- 2 àr etter at de har deltatt på kurset, for å høre deres erfaringer over tid.

\section{H vordan har du opplevd nytteverdien av kunnskap og ferdigheter om forste- hjelp ved selvmordsfare i din egen hverdag?}

\section{En prest:}

"Selv har jeg opplevd det både interessant og tilfredsstillende å få mer kunnskap og fă forbedret mine ferdigheter når det gjelder å forholde seg til mennesker i selvmordsfare. I første omgang var jeg veldig overrasket over hvor mange det faktisk er som er berørt av selvmordshandlinger i N orge bare på et år. I uformelle sammenhenger har jeg kunnet formidle kunnskap/ informasjon omkring dette vanskelige og tabubelagte tema. $0 \mathrm{~g}$ det er ikke sjelden at folk har kommet til meg med spørsmål, fordi de indirekte har stått overfor problemet og har sett på meg som en ressursperson i denne sammenheng. I dag kommer en 17 år gammel jente til meg; hun har bedt om veiledning etter at en venninne har gjort selvmordsforsøk.

\section{En politimann:}

"Jeg har hatt nytte av kurset både i arbeidssammenheng og privat. Kunnskapene fra kurset har gitt meg større bevissthet og selvtillit, slik at jeg våger å gå inn for å forsøke å hjel pe personer som sliter med selvmordstanker. Jeg har brukt og erfart at modellen vi lærte på kurset, har fungert. Dette har vært et verktøy som jeg har brukt for å forsøke å hjel pe personer i krise. Kurset hjalp meg med å forstå hvorfor hverdagen kan bli så van skelig for noen, at de ikke ønsker å leve. Kurset hjalp meg også med å bearbeide og bevisstgjøre egne holdninger til selvmord. Dette var viktig for å avklare om jeg var den rette til å kunne yte andre hjelp. Jeg er blitt mer bevisst på at jeg faktisk kan gjøre noe, og at førstehjel pshandling nødvendigvis ikke vil ta så lang tid. Kunnskapene har også vært nyttige i situasjoner der andre har opplevd at nære venner eller bekjente av dem sliter og tenker på selvmord. I disse situasjonene har jeg kunnet veilede og gitt råd om hva de kan gjøre. Tilbakemeldingene har vært gode, og flere har kommet tilbake og sagt at rădene hjalp. Kurset har ført til at jeg er mer på vakt overfor signaler på at noe kan "være galt"."

\section{En lærer:}

"Jeg har hatt stor nytte av mine kunnskaper. Jeg oppdaget at en elev var i stor selvmordsfare og fikk henne inn på BU $P$ dagen etter jeg var på kurset."

\section{H va har vært vanskelig?}

\section{En politimann:}

"Ingen situasjoner er like. Vanskeligst har vært situasjoner der noen jeg kjenner har snakket om å ta livet sitt, eller klart å gjøre det, uten at jeg oppfattet noen signaler og klarte å stanse dem. D ette ga også en viss følelse av å ha sviktet. Jeg innser at vi sannsynligvisikke kan klare å redde alle 


\section{vivat}

som ønsker å ta sitt liv. Signalene er forskjellige, og noen gir ikke signaler før det er for sent. Dette har vært en trøst i en tid der personer jeg kjenner har tatt livet sitt."

\section{En lærer:}

"Det har vært vanskelig å være den eneste i lærerstaben som har denne type kompetanse. Jeg kan bare forholde meg til min egen klasse og det går greit, men jeg ser også at det er elever i andre klasser som sliter. Ingen snakker med dem. Jeg er også avhengig av god kontakt med rådgiveren fordi jeg ikke kan henvise en elev videre i systemet. For å kunne hjelpe elever i krise er det viktig å ha et velfungerende støtteapparat.

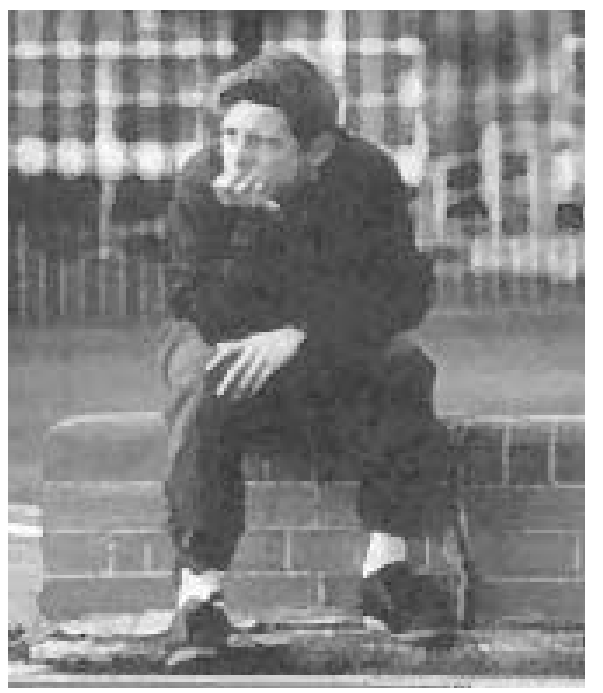

\section{H va har vært viktigst for deg av det du lærte?}

\section{En prest:}

"Synes at jeg har lært mye når det gjelder kommunikasjon og samtaleteknikk, og da mener jeg ikke teoretiske modeller, men praktisk tilnærming. Blant annet det å gå rett på sak uten å virke støtende eller fordømmende. Videre har jeg fått en mye mer bevisst holdning til det å se etter faresignaler og blitt bedre i stand til å kunne vurdere hvor alvorlige disse er. $\varnothing$ kt kunnskap om omfang/utbredelse, tolking av faresignaler og forbedret samtale- og tilnærmingsteknikk er nok det viktigste jeg har fått med meg fra kurset."

\section{En politimann:}

"A kunne fange opp signaler og vite hvilke signaler man skal se etter. A kunne foreta en risikovurdering for å klarere ut den akutte selvmordsfare, samt hvordan en samtale med en person i risikosonen kan foretas. M odellen vi lærte på kurset, har blitt en "mental førstehjelpspakke" som ligger i bakhodet, og som jeg kan ta frem ved behov."

\section{En lærer:}

"D et har vært viktig å få et verktøy som kan brukes i møte med unge mennesker."

\section{$\mathrm{H}$ ar dine kollegaer behov for dette?}

\section{En politimann:}

"Kurset er bra og har vært meget viktig for meg, både som politimann og privatperson. Som politimann vil man ganske sikkert komme i kontakt med selvmordssaker. Kunnskapen kurset gir, vil kunne berike og styrke politiets håndtering av slike saker. A lle i politiet burde ha dette kurset, helst i grunnutdanningen."

\section{En prest:}

"A lle som arbeider med mennesker, vil før eller senere ha behov for kunnskap og ferdigheter om førstehjelp ved selvmordsfare. Prestekollegaer og andre ansatte i Kirken er selvsagt ikke unntatt."

\section{En lærer:}

"M ine kollegaer har sterkt behov for et kurs som det V ivat har. Jeg mener at det burde bli obligatorisk kunnskap for alle som jobber med ungdom."

Jeg tror at disse kommentarene gjenspeiler de erfaringer vi har gjort i N orge hittil. Som kursleder etter ca. 30 kurs vil jeg hevde at folk uten helsefaglig bakgrunn ikke problematiserer "førstehjelpshandlingen" for mye. De har lett for å skjønne hovedprinsippene og kan integrere dem i den medmenneskelige omsorgen som det er naturlig å vise. V år erfaring er at mange etterpå gir tilbakemel ding om at de også har hatt stor nytte av sine ferdigheter som privatpersoner. Selvmord kan berøre oss når som helst og hvor som helst. Det kan ikke bare være et anliggende for eksperter, og vi kan heller ikke bare bruke våre ferdigheter på jobb.

Et viktig element på kurset er å lage lokale nettverk blant alle typer hjelpere. Det at førstehjelp skal kunne fungere optimalt er selvfølgelig avhengig av det neste skrittet: at det er fagpersoner som kan ta over. N oen ganger kan det være nok med en "førstehjelpssamtale", men

\section{Kort kursbeskrivelse}

"Førstehjelp ved selvmordsfare" er et intensivt kurs over to dager (14 timer). Det retter seg mot alle som i sitt virke møter selvmordsnaere mennesker. Det er et praktisk, tverrfaglig kurs hvor deltakerne laerer å oppfatte faresignaler og å gripe inn i tilfelle akutt selvmordsfare. "Førstehjelp ved selvmordsfare" gir større trygghet og mer selvtillit i møte med folk som er i alvorlig tvil om de orker å leve videre.

\section{På kurset lærer man}

- å finne ut hvordan man kan strekke ut en hjelpende hånd

- å tolke risikosignaler

- å vurdere akutt selvmordsfare

- å gjennomgå en krisesamtale

- å bruke nære ressurser i krisehjelp

ofte må oppføl ging til. Derfor er det også viktig at de som har ansvar for den første kontakten, kjenner sine begrensninger og kan koble inn andre ressurser.

På Internett (www.med.uio.no/ipsy/ssff/ vivat) finner du mer informasjon om Vivat og om neste kurslederkurs. Kanske kunne det være aktuelt for deg å bli kursleder? Vivat trenger nye kursledere, og særlig fra miljøer utenfor helse- og sosial tjenesten. U nder denne adressen vil du også finne personer som kan være behjelpelige med å arrangere kurset der du bor. Er du interessert, kontakt Vivat.

\section{VIVAT}

Regionsykehuset i Tromsø,

Psykiatrisk avdeling, 9291 Tromsø

T If. 77627819 /22 - fax 77627530

e-post: vivat@rito.no

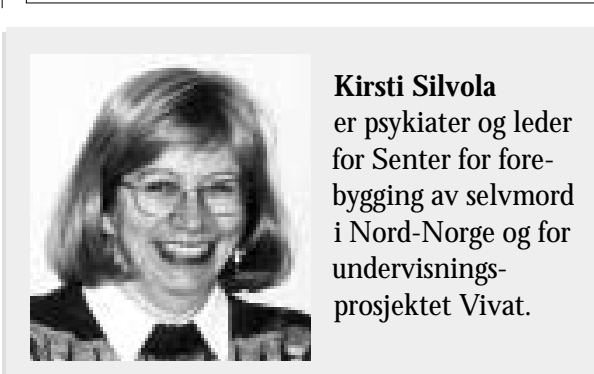

